\title{
Local Community Entrepreneurship: A Case Study of the Lenggong Valley
}

\author{
Mastura Jaafar ${ }^{1}$, Norziani Dahalan ${ }^{2} \&$ Siti Asma Mohd. Rosdi ${ }^{1}$ \\ ${ }^{1}$ The School of Housing Building and Planning, Universiti Sains Malaysia, Minden, Penang, Malaysia \\ ${ }^{2}$ The School of Distance Education, Universiti Sains Malaysia, Minden, Penang, Malaysia \\ Correspondence: Mastura Jaafar, The School of Housing Building and Planning, Universiti Sains Malaysia, \\ 11800, Minden, Penang, Malaysia. Tel: 60-4-657-5235. E-mail: masturaj@usm.my
}

\author{
Received: March 4, 2014 Accepted: March 25, 2014 Online Published: April 29, 2014 \\ doi:10.5539/ass.v10n10p226 \\ URL: http://dx.doi.org/10.5539/ass.v10n10p226
}

\begin{abstract}
Entrepreneurship has been acknowledged as the best approach to empower the socio-economic development of rural communities in various countries. Lenggong Valley is in its first phase of tourism development and entrepreneurship of local community is still under studied in Lenggong. By looking at various business activities that could be generated by the development, their involvement in business would contribute to a better economic return. The purpose of this paper is to investigate the entrepreneurship of local community in Lenggong Valley. Based on quantitative face to face survey conducted on 500 residents in Lenggong Valley, the finding indicates that some of the local communities in Lenggong are already involved in entrepreneurship activities; however their business survivability should be a concern as they face limited financial sources and support. Furthermore, the majority of them are still involve in agricultural related activities making an indication that major effort is required to transform their life-style from agriculture to entrepreneurship. The finding provides a suggestion to the government on the needs to implement various entrepreneurship related programme in Lenggong Valley. Strategies to increase their involvement could be done through innovative programs, awareness, preparedness, and education on future entrepreneurs. Having newly declared as a world heritage site, this paper demonstrates the preliminary result on the need for a deeper examination on local community entrepreneurship in Lenggong Valley.
\end{abstract}

Keywords: entrepreneurship, community participation, Lenggong Valley and tourism development

\section{Introduction}

Tourism is an industry with the potential to develop rural entrepreneurship. Sherief (2005) argued that poverty is predominantly rural, and affirms that rural development is increasingly being linked to entrepreneurship (Petrin, 1994). Entrepreneurship is crucial to economic growth. For rural areas, the benefits of entrepreneurship are undeniable. Entrepreneurship establishes the qualities of human capital to be highly skilled, resilient, and competitive, as well as innovative and creative in business (Vinten \& Alcock, 2004; Thurik \& Wennekers, 2004).

Striving for developed nation status in 2020, Malaysia has identified human capital as the most important resource and has ensured successful transformation toward becoming a high-income country. The New Economic Model (NEM) launched in 2010 emphasizes the growth of micro-scale businesses and small and medium enterprises (SMEs), and enhances the entrepreneurial ecosystem and chains. In the 6th Malaysia Plan (1992), the government introduced the concept of community development entrepreneurs through the "One Village, One Product" program, which was later known as "One District, One Industry." The objective of this program is to attract tourists to rural areas, as well as to generate income by involving villagers in the entrepreneur community development program. Based on the example of Japan, this program develops SMEs within villages by using local resources to manufacture handicrafts, food, and agricultural goods.

Lenggong is a popular cultural heritage attraction (Saidin, 2010). The attraction is situated in the Lenggong subdistrict, Hulu Perak District, Perak, Peninsular Malaysia, which is about $100 \mathrm{~km}$ from the capital, Ipoh. Lenggong valley is located between two mountain ranges, the Titiwangsa and Bintang, which make it suitable for agriculture and animal husbandry. Composed of a few villages, Lenggong is now prominent after being 
acknowledged as a World Heritage site. According to geologists, Lenggong is one of the earliest inhabited places in Malaysia, that is, about 1.83 million years ago (Saidin, Abdullah, Nordin, \& Saad, 2011). Moreover, geological studies on Bukit Bunuh, Lenggong indicated a meteorite hit this area about 1.83 million years ago (Ministry of Information, Communication, and Culture, 2011). This recognition provides an additional attraction value to Lenggong. Besides local tourist, the arrival of international visitors boosts tourism development in this area. The state government is currently taking initiatives to position Lenggong as one of the world's attractions, and for local community to participate in its development. Archeological tourism attractions will definitely spur other business activities in Lenggong. As a new tourism destination, Lenggong is locally and internationally developing its brand. Traditionally, local communities in Lenggong valley are involved in first-level economic activities, which are agriculture and fisheries (Jaafar, Rashid, Maideen, \& Mohamad, 2011). However, some residents have moved on to the third economic level, which is providing services or selling goods to other people.

Thus, entrepreneurship development is an interesting issue to discuss. In the tourism viewpoint, entrepreneurship research on archaeological sites remains a new area to explore. In Lenggong, the local community involvement in entrepreneurship activities is still at the beginning stage, while business involvement is still unknown. Therefore, the present study aims to investigate and discuss the Lenggong local community and its entrepreneurship. The findings will be discussed in view of the importance of the local community in supporting the future tourism development in Lenggong.

\section{Literature Review}

\subsection{Rural Community Involvement}

Communities can be defined as groups of individuals who work together to achieve economic development (Beck, 1992). Researchers use certain keywords to define a community, such as togetherness (Bartle, 2007) and kinship among members (Peterson, 1988). Social relations, mutual interests, and participation in common activities (Bartle, 2007) interconnect communities. A local community is defined as a group of individuals who live or work within the same geographical area, and share similar cultures or common interests. The local community is a basic element of rural tourism development (Aref, Gill, \& Aref, 2010). Besides providing support to operate tourism businesses (Godfrey \& Clarke, 2000), people in host communities can entertain tourists by sharing their culture in different places and social contexts.

Tourism is a way to spur rural economic development (Gurung \& DeCoursey, 2000). Sharpley (2000) stresses that rural tourism catalyzes socio-economic development and regeneration. Rural tourism provides new sources of income for families living in a remote rural area (Gale, 2006), and offers an agricultural resource (Petric, 2003). Tourism is also important in rural development because it generates income and employment, constituting a market for local products and facilitating the diversification of traditional poor economies by revitalizing them (Ghaderi \& Henderson, 2012). In accordance with this influence, Azman, Halim, Liu, and Komoo (2011) state that the best advantage of tourism development is that it increases the income, employment, and educational opportunities available to local communities. According to Hall (2004), rural tourism benefits local communities by providing supplementary income in the farming, craft, and service sectors; the opportunity to achieve the economic value of quality-based production of food products; and the opportunity to re-evaluate the heritage and its symbolism, environment, and identity. Thongma, Leelapattana, and Hung (2011) suggest that the involvement of local communities is instrumental to the success of rural tourism development because these communities build familiarity among tourists and impress visitors with their local cultural activities. In addition, visitors who are satisfied with their tourism experience decide to revisit the same destinations (Lo, Songan, Mohamad, \& Yeo, 2013).

A few previous studies raise issues about local communities in rural tourism, while other studies argue about the significant contributions of tourism development to local communities (Hampton, 2005; Liu, 2006; Sundin, 2011). For example, Hampton (2005) stresses the significance of high involvement among local communities in ensuring the successful development of the Indonesian tourism industry. However, rural tourism development failed to specifically plan the development to benefit the local community. The local community claim that majority of travel plans to develop a region or destination has not sufficiently considered the willingness and ability of local human resources to participate. Therefore, local human resources are marginalized from tourism development because of their inability to get involved (Sundin, 2011). By contrast, the lack of coordination, intention, and integration of local capacity impedes successful local involvement in tourism (Liu, 2006). 


\subsection{Rural Community Entrepreneurship}

Entrepreneurship provides benefits to the community so that individuals and organizations become accountable and responsible for their respective areas (Clamp \& Alhamis, 2010; Bornstein, 1998; Dees, 1999; Giddens, 1997; Kim, 1996; Osborner \& Flyn, 1997; Reis, 1999; Schuyler, 1998; Thalluber, 1998). In rural areas, entrepreneurship results from a unique combination of resources that are either inside or outside of the agricultural sector (Sherief, 2005). The economic goals of an entrepreneur and the social goals of rural development are strongly interrelated; thus, entrepreneurship in rural areas is usually community-based, has strong extended family linkages, and has a relatively significant effect on a rural community. Entrepreneurship is a key element in individual or human capital development, and helps address social issues (Vinten \& Alcock, 2004; Thurik \& Wennekers, 2004). Communities built with strong entrepreneurial foundation and environment can energize local entrepreneurs.

Vinten and Alcock (2004) considered research on rural entrepreneurship as relatively limited, and knowledge is necessary to foster the process. Local natural attractions in rural areas provide a potential tourism market for local entrepreneurial development. According to Stathopoulou, Psaltopoulos, and Skuras (2004), three major features of the physical environment significantly affect entrepreneurship: location, natural resources, and landscape. Depending on the uniqueness of each physical environment, each tourism destination can offer various attractions and provide potential opportunities to local people.

An entrepreneurial environment results from a combination of factors that play important roles in the development of new business ventures (Gnyawali \& Fogel, 1994). It refers to the overall exogenous factors that influence the willingness of people to undertake entrepreneurial activities, and the availability of assistance and support services that facilitate start-ups. According to Covin and Slevin (1991), the external environment includes economic, political or legal, and socio-cultural forces that provide a broader context for the operations of an organization. For example, Shane (2003) acknowledged the effects of specific cultural systems and the collective values of individuals on the level of entrepreneurship. Gnyawali and Fogel (1994) stated that entrepreneurship in developing economies can thrive based on two conditions: first, potential entrepreneurs find opportunities in the environment, and second, environmental conditions motivate and enhance the ability of entrepreneurs to start and manage a new business. An encouraging local environment facilitates entrepreneurship and business growth. According to Shane (2003), the environment or context includes the physical, social, cultural, and economic infrastructures of the local community within which entrepreneurial ventures are initiated. This context is a critical factor in establishing new enterprises. Communities that are confident with development strategies can improve the entrepreneurial environment (Richards \& Hall, 2000).

\section{Methodology}

This research is part of a larger study on community participation in Lenggong valley. A survey questionnaire was designed to focus on community participation in entrepreneurship. The specific part of questionnaire booklet consisted of 10 questions on the demographics, and 15 questions measured entrepreneurship participation. All questions were objective, and divided into four sections, namely, entrepreneurship involvement, business promotion, networking, and entrepreneurship knowledge.

This research conducted the quantitative method of data collection from April to May 2012. The stratified random sampling method was employed to distribute the questionnaire among the local community according to districts and villages. Lenggong is represented by three districts, namely, Lenggong, Temelong, and Durian Pipit, which have six, eight, and nine villages, respectively. Lenggong valley has 16,320 residents.

Cooper (2008) recommended a sample of $10 \%$ of the parent population. McQueen and Knussen (2002) emphasized the importance of having a large sample size to increase the possibilities of attaining statistical reliability. Using random sampling technique, the present study selected 500 local communities in Lenggong as respondents. Data collection was done by using a personal survey from the three districts of Lenggong valley.

\section{Analysis}

The results of analysis represented in Table 1 shows the demographic profile of the local community. Majority of the respondents are residents (90.6\%) of Lenggong valley, whereas only $9.4 \%$ are not residents. Female respondents comprise $52.2 \%$, and only $47.8 \%$ of the respondents are male. With regard to marital status, $59.4 \%$ of the respondents are married, $32.4 \%$ are single, and $8.2 \%$ are single parents. More than half of the respondents are Malays (59.4\%), followed by the Chinese (24.4\%), and the Indians (16.0\%). Most of the respondents are between 46 to 55 years old (22.6\%), followed by 26 to 35 years old (22\%), and young respondents aged from 25 and below comprise $21.6 \%$. In terms of educational background, few respondents $(11.2 \%)$ obtain higher 
education (college, institute, or university). Most of them finished higher level of education (56.0\%), whereas $32.8 \%$ completed secondary school.

In terms of occupation, most respondents are self-employed (54.8\%). Some respondents are employed in private companies $(29.0 \%)$, while a few $(16.2 \%)$ work in the government sector. Agriculture and food are the two prominent involvement sectors, with $38.0 \%$ and $30.8 \%$, respectively, followed by business $(20.0 \%)$. Regarding the work experience of the respondents, majority have worked less than 5 years $(49.0 \%)$, followed by 6 to 10 years $(22.8 \%)$, and 11 to 15 years $(14.4 \%)$.

Table 1. Profile of respondents

\begin{tabular}{|c|c|c|c|}
\hline Description & Criteria & Frequency & Percentage \\
\hline \multirow{2}{*}{ Residency } & Yes & 453 & 90.6 \\
\hline & No & 47 & 9.4 \\
\hline \multirow{3}{*}{ Gender } & Male & 239 & 47.8 \\
\hline & Female & 261 & 52.2 \\
\hline & Married & 297 & 59.4 \\
\hline \multirow[t]{3}{*}{ Marital Status } & Not married & 162 & 32.4 \\
\hline & Single Parent & 41 & 8.2 \\
\hline & Malay & 297 & 59.4 \\
\hline \multirow[t]{4}{*}{ Race } & Chinese & 122 & 24.4 \\
\hline & Indian & 80 & 16.0 \\
\hline & Other & 1 & 0.2 \\
\hline & Less than 25 & 108 & 21.6 \\
\hline \multirow[t]{6}{*}{ Age } & 26 to 35 years old & 110 & 22.0 \\
\hline & 36 to 45 years old & 93 & 18.6 \\
\hline & 46 to 55 years old & 113 & 22.6 \\
\hline & More than 56 years old & 76 & 15.2 \\
\hline & Primary school & 164 & 32.8 \\
\hline & Secondary school & 108 & 21.6 \\
\hline \multirow[t]{5}{*}{ Education } & Finished SPM & 172 & 34.4 \\
\hline & Diploma & 39 & 7.8 \\
\hline & Degree & 15 & 3.0 \\
\hline & Master/PhD & 2 & 0.4 \\
\hline & Government & 81 & 16.2 \\
\hline \multirow[t]{3}{*}{ Occupation } & Private & 145 & 29.0 \\
\hline & Self-employed & 274 & 54.8 \\
\hline & Agriculture & 190 & 38.0 \\
\hline \multirow{2}{*}{ Sector involvement in entrepreneurship } & Fishing & 20 & 4.0 \\
\hline & Business & 100 & 20.0 \\
\hline \multirow{6}{*}{ Income } & Food & 154 & 30.8 \\
\hline & Others & 36 & 7.2 \\
\hline & Less than RM 1000 & 261 & 52.2 \\
\hline & RM 1001-RM 2000 & 185 & 37.0 \\
\hline & RM 2001-RM 3000 & 40 & 8.0 \\
\hline & RM 3001 and above & 14 & 2.8 \\
\hline
\end{tabular}




\begin{tabular}{|c|c|c|c|}
\hline Description & Criteria & Frequency & Percentage \\
\hline \multirow{7}{*}{ Work experience } & 1 to 5 years & 245 & 49.0 \\
\hline & 6 to 10 years & 114 & 22.8 \\
\hline & 11 to 15 years & 72 & 14.4 \\
\hline & 16 to 20 years & 24 & 4.8 \\
\hline & 21 to 25 years & 11 & 2.2 \\
\hline & 26 to 30 years & 24 & 4.8 \\
\hline & 31 years and above & 10 & 2.0 \\
\hline
\end{tabular}

Table 2 shows the local community involvement in entrepreneurship. Majority of the respondents have experience being involved in small business (40.8\%), whereas the rest have not. Regarding the period of their involvement, $40.2 \%$ have been involved for 6 years and above, followed by less than 1 year $(31.4 \%)$ and 1 to 5 years $(28.4 \%)$. Getting higher income is the benefit they gained in their involvement $(43.1 \%)$, followed by satisfaction (35.3\%), and others (21.6\%).

Not having enough capital was rated as the main reason for leaving the business $(38.2 \%)$, followed by other factors, such as age (22.5\%), health (17.2\%), poor management (14.7\%), and others $(11.2 \%)$. Regarding problems encountered during the running of the business, majority answered having not enough capital (38.7\%), followed by no support (21.6\%), failure to compete in the business $(14.7 \%)$, and the absence of customers $(14.2 \%)$.

In terms of networking, the respondents ranked the people with whom they deal most in doing business. The highest is their relatives $(31.4 \%)$, followed by friends $(23.5 \%)$, head of villages $(17.6 \%)$, and government officers (10.8\%). In their involvement in any association, majority was not involved in associations (62.78). Then, $72.1 \%$ have not attended any training or workshop. Only $19.1 \%$ have attended workshops arranged by the government, whereas only $11.3 \%$ attended private workshops. No prominent workshop was specified by the respondents. Only two respondents $(1.0 \%)$ attended fisheries workshop, three (13.7\%) attended agricultural, and four $(1.96 \%)$ attended food-related courses, whereas, other courses are related to sewing, craft, automotive, entrepreneurship, and business. However, 93.6\% have not applied any of the aforementioned activities after the training.

With regard to having knowledge about financial facilities, the respondents who answered yes and no are close in number ( $50.5 \%$ and $49.5 \%$, respectively). Regarding their knowledge of available financial facilities, majority chose Amanah Ikhtiar (22.5\%), followed by TEKUN (17.6\%), and MARA (5.9\%). In terms of their action if they would be given an opportunity to start a business, majority said they would find a place (30.9\%), others said they would find capital (29.4\%), find business partners (13.2\%), and find information (10.3\%). In response to what or who can encourage local community involvement in entrepreneurship, the respondents chose attitude change (26.5\%), followed by government effort (22.5\%), opportunity (22.1\%), and knowledge (19.6\%).

Table 2. Local community involvement in entrepreneurship

\begin{tabular}{llc}
\hline & Frequency & Percentage \\
\hline Involvement in small business & 204 & 40.8 \\
Yes & 296 & 59.2 \\
No & & 31.4 \\
Period of involvement in small business & 64 & 28.4 \\
Less than 1 year & 58 & 40.2 \\
1 to 5 years & 82 & \\
6 years and above & & 35.3 \\
Benefit of involvement in entrepreneurship & 72 & 43.1 \\
Satisfaction & 88 & 21.6 \\
Higher income & 44 \\
Others & & 38.2 \\
Reason for stopping from being involved & 78 \\
Not enough capital & 46 & 22.5 \\
Age & & \\
\hline
\end{tabular}




\begin{tabular}{|c|c|c|}
\hline & Frequency & Percentage \\
\hline Health & 35 & 17.2 \\
\hline Poor management & 30 & 14.7 \\
\hline Others & 15 & 7.4 \\
\hline \multicolumn{3}{|c|}{ Problem encountered during running the business } \\
\hline Not enough capital & 79 & 38.7 \\
\hline No support & 44 & 21.6 \\
\hline Failure to compete & 30 & 14.7 \\
\hline No customer & 29 & 14.2 \\
\hline Weather & 8 & 3.9 \\
\hline Others & 14 & 6.9 \\
\hline \multicolumn{3}{|c|}{ People with whom they deal in doing the business } \\
\hline Relatives & 64 & 31.4 \\
\hline Friends & 48 & 23.5 \\
\hline Head of villages & 36 & 17.6 \\
\hline Government officials & 22 & 10.8 \\
\hline Political figures & 10 & 4.9 \\
\hline All of the above & 8 & 3.9 \\
\hline Others & 16 & 7.8 \\
\hline \multicolumn{3}{|c|}{ Involvement in any association } \\
\hline Yes & 76 & 37.3 \\
\hline No & 128 & 62.7 \\
\hline \multicolumn{3}{|c|}{ Attendance in training/workshop } \\
\hline Yes & 57 & 27.9 \\
\hline No & 147 & 72.1 \\
\hline \multicolumn{3}{|c|}{ Organization of workshop } \\
\hline Private & 23 & 11.3 \\
\hline Government & 39 & 19.1 \\
\hline Not applicable & 142 & 69.6 \\
\hline \multicolumn{3}{|c|}{ Have knowledge on financial facilities } \\
\hline Yes & 103 & 50.5 \\
\hline No & 101 & 49.5 \\
\hline \multicolumn{3}{|c|}{ Available financial facilities } \\
\hline TEKUN & 36 & 17.6 \\
\hline Amanah Ikhtiar & 46 & 22.5 \\
\hline MARA & 12 & 5.9 \\
\hline Others & 17 & 8.3 \\
\hline Not applicable & 93 & 45.6 \\
\hline \multicolumn{3}{|l|}{ Total } \\
\hline \multicolumn{3}{|c|}{ Action if given opportunity to start a business } \\
\hline Find place & 63 & 30.9 \\
\hline Find capital & 60 & 29.4 \\
\hline Find business partner & 27 & 13.2 \\
\hline Find information & 21 & 10.3 \\
\hline Find mentor & 9 & 4.4 \\
\hline Others & 11 & 5.4 \\
\hline All above & 13 & 6.4 \\
\hline \multicolumn{3}{|c|}{ Means to encourage local community participation in entrepreneurship } \\
\hline Attitude change & 54 & 26.5 \\
\hline Government effort & 46 & 22.5 \\
\hline Find opportunity & 45 & 22.1 \\
\hline Find knowledge & 40 & 19.6 \\
\hline Others & 5 & 2.5 \\
\hline All of the above & 14 & 6.9 \\
\hline
\end{tabular}




\section{Discussion}

This paper has explored the conditions of entrepreneurship in a local community in the archaeological site of Lenggong valley, peninsular Malaysia. The recognition of Lenggong as a UNESCO World Archaeological Heritage site boosts its tourism development. Similarly, the local community has been exposed to various business opportunities that enabled them to launch entrepreneurship ventures. Majority of the residents of Lenggong valley are Malays. The area has yet to be exposed to the kind of development in which tourism can attract outsiders to venture into business or provide work opportunities.

The survey respondents are mostly married, have varied age ranges, and only a few obtained higher education. Most of the respondents are self-employed and some work in the private sector. The most popular ventures are in the agricultural, food, and business sectors. The monthly income of respondents is below RM 2,000. Local community involvement focuses on the agricultural and fisheries sector, whereas the business set-up relates closely to the availability of local resources. Accordingly, an equal entrepreneurship involvement was found on the basis of gender and race. However, married respondents aged 26 years and above are more actively involved in entrepreneurship compared with other age groups.

Similar to the common practice of entrepreneurship in the local community, most of the respondents have not been involved in entrepreneurial activities, and less than half the number of respondents can sustain their business for more than six years. Majority of them are involved to earn extra income and satisfaction. However, the most common reason for business discontinuity is the problem with capital and personal limitation caused by age and health. The respondents indicated that they could be discouraged because of limited capital, difficulties in obtaining support, and failure to compete in their respective markets.

The local individuals received significant support from their relatives, aside from friends and village leaders. These individuals still have narrow perceptions on the importance of networking and linkages by joining associations or attending trainings or courses (Ateljevic, 2009). The government also plays a major role in developing local entrepreneurship. However, it has not exerted sufficient effort to train the local community (Ateljevic, 2009). The local community mentioned its involvement in various workshops even without focusing on specific targets or achievements. The aim of the government through the program "One Village, One Industry" is not effectively conducted in Lenggong.

Moreover, half of the respondents have no knowledge of financial facilities, and the most popular financial association they know are Amanah Ikhtiar and TEKUN. Amanah Ikhtiar is a private trust established to assist less fortunate groups and reduce poverty in Malaysia by financing activities to increase the income of poor communities in rural areas. TEKUN, an agency under the Ministry of Entrepreneur and Cooperative Development, was established in 1998 to provide fast and easy financing for locals to start and develop their own businesses. These two bodies are popular among rural people who want to obtain an allocation for their businesses. The local community should be provided with specific locations, financial facilities, knowledge, and guidance to enable them to start businesses. The respondents expressed their hope for the government to help transform the local economy into one that is characterized by entrepreneurship and business. Providing knowledge and opportunity is a major step to involve the local community in entrepreneurship. Currently, the government exerts effort in arranging related and useful courses at a minimum level. The respondents only rely on their own resources and limited assistance is provided by communities. Lack of community support would discourage local community involvement in entrepreneurship (Richards \& Hall, 2000). The results are in accordance with the literature that presents constraints for entrepreneurs in the tourism section such as lack of expertise in business, lack of access to financial resources, and managerial flaws (Ateljevic \& Doorne, 2000; Irvine \& Anderson, 2004; Ateljevic, 2009).

The preceding discussion highlights the important role of exogenous factors, particularly the local government, in facilitating and encouraging entrepreneurship (Covin \& Slevin, 1991). Slow progress in entrepreneurship can be traced to the passive actions of the accountable parties who are supposed to encourage entrepreneurship. The real opportunities have not been explored. Local residents might have difficulty escaping from their traditional culture and norm to start their entrepreneurial venture, as argued by Morrison (1998) and Shane, Locke, and Collins (2003). With minimal internal drive and weak motivation among the locals, outsiders might grab the opportunities instead. Such a case would illustrate the failure of the local community to benefit from tourism development, as emphasized by Sundin (2011) and Liu (2006). 


\section{Conclusion}

Majority of the population in the Lenggong Valley, a new developing rural area, have only secondary formal education and are still dependent on the first level of economic income. Among the residents, $40 \%$ have set up small businesses. With a monthly income below RM 2,000, most of them intend to become entrepreneurs to gain additional income from their small businesses. Limitations such as personal discouragement and lack of capital resulting from lack of support have caused them to leave the industry. These residents were heavily dependent on relatives and friends and were weakly involved in networking and training. In addition, these residents have limited knowledge in finding external capital and rely mainly on facilities provided by Amanah Ikhtiar and TEKUN.

The above result highlighted that the local community involvement in entrepreneurship activities has been very minimal in Lenggong valley, thus requiring strong support and guidance. To look forward to an active participation of government in encouraging entrepreneurship is important. Toward the achievement of the NEM, the Malaysian government should continuously support entrepreneurship development. In general, the government has taken various steps to promote the development of entrepreneurship including providing convenient economic environments, various financing resources, and funding schemes to spur the entrepreneurship development of the local community. Future successful entrepreneurship developments require the active participation of multiple sectors of the community, including government, business, finance, education, and social support.

Considering the significant development in Lenggong Valley, the government needs to focus on developing and empowering the existing entrepreneurship program with specific targets of achievement. With a limited number of respondents who attended trainings, few established business, and less knowledge on financial facilities, more information should be provided to the local community. The poor follow-up activities hamper the success of entrepreneurship programs. Fundamental changes on future economic activity in Lenggong valley would require policymakers to take a fresh look at the local community involvement and development. Many community development strategies used in the past would not simply produce the desired economic results when applied in Lenggong Valley. Another challenge is to strengthen the entrepreneurial culture in the local community through various strategies, such as innovative programs, awareness, preparedness, and education on entrepreneurial practices. The importance of the environment needs special consideration on sustainability issues. Having the agricultural sector involved in the main supporting activities, the development should not jeopardize the main economic activity. However, having development guidelines would help ensure that the development will be conducted with a minimal effect to the natural environment and the advantages of local community will be cared for.

\section{Acknowledgements}

This report represents part of the findings from Sustainable Tourism Research Cluster (STRC) research grant, account number 1001/PTS/8660012.

\section{References}

Aref, F., Gill, S. S., \& Aref, F. (2010). Tourism development in local communities: As a community development approach. Journal of American Science, 6(2), 155-161.

Ateljevic, I., \& Doorne, S. (2000). 'Staying Within the Fence': Lifestyle Entrepreneurship in Tourism. Journal of sustainable tourism, 8(5), 378-392. http://dx.doi.org/10.1080/09669580008667374

Ateljevic, J. (2009). Tourism entrepreneurship and regional development: Example from New Zealand. International Journal of Entrepreneurial Behaviour \& Research, 15(3), 282-308. http://dx.doi.org/10.1108/13552550910957355

Azman, N., Halim, S. A., Liu, O. P., \& Komoo, I. (2011). The Langkawi Global Geopark: Local community's perspectives on public education. International Journal of Heritage Studies, 17(3), 261-279. http://dx.doi.org/10.1080/13527258.2011.557863

Bartle, P. (2007). What is community? A Sociological Perspective. Retrieved from http://cec.vcn.bc.ca/cmp/whatcom.htm

Beck, U. (1992). Risk Society: Towards a New Modernity. London: Sage.

Bornstein, D. (1998). Changing the world on a shoestring. Retrieved from http://www.Theatlantic.com/issues/98jan/ashoka.htm

Clamp, C. A., \& Alhamis, I. (2010). Social Entrepreneurship in the Mondragon Co-operative Corporation and 
the Challenges of Successful Replication. Journal of Entrepreneurship, 19(2), 149-177. Retrieved from http://www.celcee.edu/products/digest/dig98-7html; http://dx.doi.org/10.1177/097135571001900204

Cooper, D. R., \& Schindler, P. S. (2008). Business Research Methods. New York, NY: McGraw-Hill.

Covin, J. G., \& Slevin, D. P. (1991). A Conceptual Model of Entrepreneurship as Firm Behavior, Entrepreneurship Theory and Practice, 16(1), 7-25. Retrieved from http://ssrn.com/abstract=1504448

Dees, G. (1999). The meaning if social entrepreneurship. Retrieved from http://gsb.stanford.edu/csi/SEDefinition.html

Gale, T. E. (2006). Finding Meaning in Sustainability and a Livelihood Based on Tourism: An Ethnographic Case Study of Rural Citizens in the Aysen Region of Chile. ProQuest.

Giddens, A. (1997). The Third Way: The Renewal of Social Democracy. Cambridge, UK: Polity Press.

Gnyawali, D. R., \& Fogel, D. S. (1994). Environments for entrepreneurship development: Key dimensions and research implication, Entrepreneurship, theory and practice, 43-62.

Godfrey, K., \& Clarke, J. (2000). The tourism development handbook: A practical approach to planning and marketing. London: Continuum.

Gurung, C. P., \& DeCoursey, M. A. (2000). Too much too fast: Lesson from Nepal's Lost Kingdom of Mustang. Tourism and Development in Mountain Regions CABI, Oxon/New York, 239-253.

Hall, D. (2004). Rural tourism development in south Eastern Europe: Transition and the search for sustainability. International Journal of Tourism Research, 6(3), 165-176. http://dx.doi.org/10.1002/jtr.482

Hampton, M. P. (2005). Heritage, local communities and economic development. Annals of Tourism Research, 32(3), 735-759. http://dx.doi.org/10.1016/j.annals.2004.10.010

Irvine, W., \& Anderson, A. R. (2004). Small tourist firms in rural areas: Agility, vulnerability and survival in the face of crisis. International Journal of Entrepreneurial Behaviour \& Research, 10(4), 229-246. http://dx.doi.org/10.1108/13552550410544204

Jaafar, M., Rashid, A. A. A., Maideen, S. A., \& Mohamad, S. Z. (2011). Entrepreneurship in the tourism industry: Issues in developing countries. International Journal of Hospitality Management, 30, 827-835. http://dx.doi.org/10.1016/j.ijhm.2011.01.003

Kim, D. (1996). The emergence of policy entrepreneurs in local government. Public Money and Management, 1(1), 291-301.

Liu, A. (2006). Tourism in rural areas: Kedah, Malaysia. Journal of Tourism Management, 27, 878-889. http://dx.doi.org/10.1016/j.tourman.2005.05.007

Lo, M. C., Songan, P., Mohamad, A. A., \& Yeo, A. W. (2013). Rural Tourism and Destination Image: Community Perception in Tourism Planning.

McQueen, R., \& Knussen, C. (2002). Research Methods for Social Science, an Introduction. Pearson Education, Harlow.

Ministry of Information, Communication and Culture. Department of National Heritage. (2011). Archaeological Heritage of the Lenggong Valley. Nomination Dossier for Inscription on the UNESCO World Heritage List. Malaysia.

Morrison, A. (1998). Entrepreneurship: An international perspective. Butterworth-Heinemann Woburn, MA.

National Trust for Historic Preservation. (2001). Heritage Tourism Program. Retrieved from http://www.nthp.org/heritagetourism/index.html

Osborne, S., \& Flynn, N. (1997). Managing the innovative capacity of voluntary and non-profit organisations in the provision of public services. Public Money and Management, 17(4), 31-39. http://dx.doi.org/10.1111/1467-9302.00089

Peterson, R. (1988). Understanding and encouraging entrepreneurship internationally. Journal of Small Business Management, 26(2), 1-7.

Petrin, L. (2003). Constraints and possibilities of the rural tourism development with the special stress on the case of Crotia. Paper presented at the ERSA conference papers.

Petrin, T. (1994). Entrepreneurship as an economic force in rural development. Keynote paper presented at the Seventh FAO/REU International Rural Development Summer School. 
Reis, T. (1999). Unleashing the New Resources and Entrepreneurship for the Common Good: A Scan, Synthesis and Scenario for Action. Battle Creek, MI: W.K. Kellogg.

Richards, G., \& Hall, D. (2000). Tourism and sustainable community development. New York: Routledge. http://dx.doi.org/10.4324/9780203464915

Saidin, M. (2010). Bukti Prasejarah Di Malaysia. Dewan Bahasa dan Pustaka, Kuala Lumpur, Malaysia.

Saidin, M., Abdullah, J., Mohd, N. M. N., \& Saad, R. (2011). Out of Malaysia: An Emerging view of early human migration, transforming higher education for a sustainable tomorrow delivering excellence: World's First Initiative. Universiti Sains Malaysia. Malaysia.

Schuyler, G. (1998). Social entrepreneurship: A profit as a means, not as an End. In Kauffman Centre for Entrepreneurial Leadership. Clearing House on Entrepreneurial Education.

Shane, S., Locke, E. A., \& Collins, C. J. (2003). Entrepreneurial motivation. Human Resource Management Review, 13(2), 257-279. http://dx.doi.org/10.1016/S1053-4822(03)00017-2

Sharpley, R. (2000). Tourism and sustainable development: Exploring the theoretical divide. Entrepreneurship and social and community care. Journal of sustainable tourism, 8(1), 1-19. http://dx.doi.org/10.1080/09669580008667346

Sherief, S. R. (2005). Entrepreneurship as an economic force in rural development. Magnus School of Business, Chennai, India. Retrieved from http://www.africaeconomicanalysis.org/articles/gen/rural entrepreneurship.html

Stathopoulou, S., Psaltopoulos, D., \& Skuras, D. (2004). Rural entrepreneurship in Europe: A research framework and agenda. International Journal of Entrepreneurial Behaviour \& Research, 10(6), 404-425. http://dx.doi.org/10.1108/13552550410564725

Sundin, E. (2011). Entrepreneurship and social and community care. Journal of Enterprising Communities: People and Places in the Global Economy, 5(3), 212-222. http://dx.doi.org/10.1108/17506201111156689

Thalluber, J. (1998). How non profit and for-profit entrepreneurs differ. Retrieved from http://www.socialentrepreneurs.org/entedef.html

Thongma, W., Leelapattana, W., \& Hung, J. T. (2011). Tourist's satisfaction Towards Tourism Activities Management of Maesa Community, Pongyang Sub-District, Maerim District, Chiang Mai Provice, Thailand. Asian Tourism Management, 65, 86.

Thurik, A. R., \& Wennekers, S. (2004). Entrepreneurship, Small Business and Economic Growth. Journal of

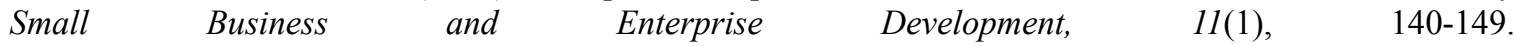
http://dx.doi.org/10.1108/14626000410519173

Vinten, G., \& Alcock, S. (2004). Community Leaders, Business Ownership, and Support of Entrepreneurship Development: The Role of Macro-entrepreneurs Entrepreneuring in education. International Journal of Educational Management, 18(3), 188-195. http://dx.doi.org/10.1108/09513540410527185

\section{Copyrights}

Copyright for this article is retained by the author(s), with first publication rights granted to the journal.

This is an open-access article distributed under the terms and conditions of the Creative Commons Attribution license (http://creativecommons.org/licenses/by/3.0/). 